\title{
Research and Analysis on Issued Inventory Valuation Methods of Enterprises
}

\author{
Shusheng Gu \\ School of accounting \\ Jiangxi University of Finance and Economics \\ Nanchang, China 330013 \\ gsswell@sina.com
}

\begin{abstract}
This paper, based on the issued inventory valuation methods stipulated in current accounting standards of China, analyzes the different effectiveness resulting from the choices of different inventory valuation method. Taking the actual situation of the international and domestic environment into account, and by adopting the method of case analysis and material analysis, this paper puts forward suggestions and advocates the comprehensive learning of different issued inventory valuation methods under the guidelines of different accounting standards, drawing on their advantages so as to develop new issued inventory valuation methods which are more suitable for the future economic situation.
\end{abstract}

Keywords-inventory; valuation method; current situation; suggestions

Inventory is an asset of significance in enterprise.Different calculation methods can be applied in different production process. Moreover, the methods will be different according to different inventory system. This paper only discusses about pricing method in terms of inventory ex-factory. There will be difference in final accounting information when different issued inventory valuation method used.

\section{INTRODUCTION OF INVENTORY VALUATION METHOD}

The inventory valuation methods are undergoing constant change and development, during which there are several methods as follows: 1) Methods on the condition of non-actual cost: planned cost method, fixed cost method, and selling price method. 2) Methods on the condition of actual cost: first, methods based on time sequence include FIFO (first-in, first-out) method, LIFO (last-in, first-out) method, moving weighted average method, and next-in first-out method. Second, methods based on unit price include specific identification method, high-price, first-out method, low-price, first-out method, and last invoice price method. [1] Third, weighted average at the end of month method, and basic stock method.

Although there are lots of methods of inventory valuation, enterprises are restricted to some degree in the choice of pricing method in terms of inventory ex-factory, no matter in which country's accounting system or the IAS(International Accounting Standards). This paper will analyze the pricing methods in terms of inventory ex-factory based on current accounting standards in our country, combined with United States Generally Accepted Accounting Principles and International Accounting Standards.

\section{CHOICES OF ISSUED INVENTORY VALUATION METHODS}

\section{A. Factors That Should Be Taken into Account in Selecting} Issued Inventory Valuation Methods

The choice of accounting policies relates to the disclosure of corporate information, and businesses can result in different accounting information by choosing different pricing methods in issuing inventory, so as to affect the operation of enterprises. Therefore, it is quite necessary to choose a pricing method that applied to a specific enterprise. [2]And enterprises should consider the following aspects when selecting the pricing methods.

1) Intrinsic Characteristics of Inventory

The inventory management policies of an enterprise need to be specified according to the enterprise's own characteristics. Pricing method in issuing inventory is closely related to the enterprise inventory management, so it's quite necessary to choose a method that corresponds to the characteristics of inventories in an enterprise.

There is no doubt that specific identification method is more accurate in inventory valuation when an enterprise has few accounting about the quantity of inventory, or the issuing and receiving of inventory is not frequent. But if the enterprise has large amounts of inventory with great varieties, and the issuing and receiving is frequent, using specific identification method can generate considerable workload. Inevitably, it will lead to greater cost and make it difficult to manage inventory.

It is specified in the IAS that specific identification method should be adopted in the inventory items that cannot be exchanged directly, and those goods or services that produced or stored for specific projects. Though there is no specific regulation about the application of specific identification method in our country, [3] this method is seldom used because it can make the operation complicated and raise the cost of inventory management. In the majority of enterprises, using FIFO method and weighted average method by considering the characteristics of inventory itself can simplify the pricing procedure and reduce the enterprise cost to some degree.

\section{2) Influence on Enterprises}

The influence of pricing method on enterprises is one of the factors that the enterprise should take into account in choosing appropriately the issued inventory valuation method.

First, different accounting policies can have different degrees of influence on inventory balance and the current 
cost of sales. Thus it will influence the enterprise asset, current profit, current cash flow, overall financial ratios (influence on the enterprise financial analysis) and tax issues like income tax.

Second, it will influence the valuation of the operating performance among enterprises to a certain degree. [4]Besides many other indicators, the final value of inventory balance is an important indicator in the comparison of the operating performance within the same industry or among the enterprises. Different inventory valuation methods will definitely result in different final inventory values, thus influence the enterprise operating performance indirectly.

\section{B. An Example to Compare the Accounting Information Resulting from Different Inventory Valuation Methods}

Rising prices is one of the current hot economic topics. Then what effect can different inventory valuation methods produce in the case of rising prices? In order to make it more intuitive and convenient to judge the results from different inventory valuation methods, what follows will analyze it with an example, together with a table.

Supposing Company A's inventory planning cost is 60 , the initial material cost difference is 1000 . The issuing and receiving of inventory of the enterprise in January is shown in the following table.

TABLE I. COMPANY A's INVENTORY IN JAN.1

\begin{tabular}{|l|c|c|c|c|}
\hline $\begin{array}{c}\text { Inventory } \\
\text { Situation }\end{array}$ & Quantity & Unit price & $\begin{array}{l}\text { Balance } \\
\text { quantity }\end{array}$ & Date \\
\hline $\begin{array}{c}\text { Opening } \\
\text { Balance }\end{array}$ & & 50.00 & 100 & Jan.1 \\
\hline Purchasing & 500 & 60.00 & 600 & Jan.3 \\
\hline Issuing & 300 & & 300 & Jan.5 \\
\hline Purchasing & 200 & 70.00 & 500 & Jan.14 \\
\hline Purchasing & 100 & 75.00 & 600 & Jan.17 \\
\hline Issuing & 400 & & 200 & Jan.22 \\
\hline Purchasing & 150 & 80.00 & 350 & Jan.28 \\
\hline Issuing & 200 & & 150 & Jan.30 \\
\hline $\begin{array}{c}\text { Closing } \\
\text { Balance }\end{array}$ & & & 150 & \\
\hline
\end{tabular}

(1)Specific identification Method

When the specific identification method is used, the cost flow is completely in consistent with the inventory flow. Thus, this method is the most accurate. The final inventory value and cost of sales are in consistent with the actual situation. Due to the particularity of this method, no comparison will be made here about it, [5] and methods that lead to difference between cost flow and inventory flow will be discussed.

(2)The accounting results from other issued inventory valuation methods are shown in Table 2 .

TABLE II. ACCOUNTING RESULTS FROM DIFFERENT ISSUED INVENTORY VALUATION METHODS

\begin{tabular}{|c|c|c|}
\hline & $\begin{array}{c}\text { Current Issued } \\
\text { Inventory Cost }\end{array}$ & $\begin{array}{c}\text { Closing Inventory } \\
\text { Value }\end{array}$ \\
\hline $\begin{array}{c}\text { Weighted average at } \\
\text { the End of Month } \\
\text { Method }\end{array}$ & $58,714.29$ & $9,785.71$ \\
\hline $\begin{array}{c}\text { Moving Weighted } \\
\text { average Method }\end{array}$ & $57,785.71$ & $10,714.29$ \\
\hline
\end{tabular}

\begin{tabular}{|l|l|l|}
\hline FIFO Method & $56,500.00$ & $12,000.00$ \\
\hline Planned Cost Method & $58,714.29$ & $9,785.71$ \\
\hline LIFO Method & $60,500.00$ & $8,000.00$ \\
\hline
\end{tabular}

As shown in table 2.2, in the case of rising prices, different inventory valuation methods can result in different current carry-over inventory cost and inventory balance.

Among these methods, the combining use of planned cost method and weighted average at the end of month method lead to the same accounting method as the weighted average at the end of month method. [6]

As for the other pricing methods, LIFO method results in the greatest current carry-over inventory cost, while the FIFO method leads to the largest current inventory balance. Therefore, among these internationally existing inventory valuation methods, in the case of rising prices, LIFO method results in the least profit, and income tax; FIFO method results in greatest profit and income tax, accompanied by low cash inflows, and high operating cost.

On the contrary, in the case of falling prices, we can draw the opposite conclusion.

\section{THE PROBLEMS THAT THE ISSUED INVENTORY VALUATION SYSTEM FACES}

Under the circumstance of global convergence of accounting principles, the whole issued inventory valuation system is developing towards being more scientific and united. During the process, however, there are still some problems hindering the inventory calculation and management of enterprises. Firstly, globally, especially domestically, the proportions of actual choices of the inventory valuation methods are, to some degree, seriously unbalanced. Secondly, with the continuously increasing or decreasing commodity prices, the existing inventory valuation methods are insufficient in correctly reflecting accounting information, which has an effect on both enterprises and market.

\section{A. Imbalanced Proportions of Choices of Issued Inventory Valuation Methods}

Compared with other methods, the FIFO method is closer to the actual flow of products for most enterprises. Therefore, the FIFO method is more suitable for the actual flow of inventory, which benefits the management of the inventory in the enterprises and makes the inventory balance closer to the market value. But the actual usage of the FIFO method is much less frequent than that of the Weighted Average method.

1) Choices of Issued Inventory Valuation Methods Globally

The data in Table 3 are the division of choices of issued inventory valuation methods of the listed enterprises of various countries in 2009. From the table, we can see that in the choices of issued inventory valuation methods, the number of choosing the Weighted Average method is clearly lager than that of choosing the FIFO method. The former is nearly as two times as the latter. 
TABLE III. CHOICES OF INVENTORY POLICIES IN DIFFERENT COUNTRIES (SAMPLE SIZE:179)

\begin{tabular}{|c|c|c|c|c|}
\hline Country & FIFO & $\begin{array}{l}\text { Weighted } \\
\text { average }\end{array}$ & $\begin{array}{l}\text { Combination of } \\
\text { Two Methods }\end{array}$ & $\begin{array}{c}\text { Total } \\
\text { Number }\end{array}$ \\
\hline Australian & 6 & 9 & 2 & 17 \\
\hline British & 10 & 11 & 2 & 23 \\
\hline China & 1 & 25 & 1 & 27 \\
\hline France & 5 & 15 & 7 & 27 \\
\hline Germany & 4 & 10 & 2 & 16 \\
\hline Italy & 1 & 7 & 0 & 8 \\
\hline $\begin{array}{c}\text { New } \\
\text { Zealand }\end{array}$ & 9 & 6 & 1 & 16 \\
\hline Sweden & 7 & 0 & 0 & 7 \\
\hline Switzerlan & 3 & 5 & 1 & 9 \\
\hline Spain & 0 & 3 & 1 & 4 \\
\hline $\begin{array}{c}\text { Other } \\
\text { European } \\
\text { countries }\end{array}$ & 13 & 10 & 2 & 25 \\
\hline $\begin{array}{c}\text { Total } \\
\text { Number }\end{array}$ & 59 & 101 & 19 & 179 \\
\hline
\end{tabular}

Source: Lao Chuanqi, 2011, Research on Accounting Cultural Background of Global Convergence of Accounting Principles

\section{2) Choices of Issued Inventory Valuation Methods} Domestically

In China, the imbalance of the choices of inventory valuation methods is more obvious. From the Table 3, we can see that 25 out of 27 of the enterprises listed abroad apply the weighted average method. The other companies combine the two methods. Table 4 collects the choices of inventory valuation methods of 897 enterprises listed in China in the end of 2005 and 2009. The Table presents that after the prohibition of the LIFO method in China, the enterprises whose valuation method was LIFO has to choose other ones, among which the FIFO method gains an increased usage of $1.02 \%$ while the weighted average method and specific identification method suffer a heavy decline. Besides, the weighted average method has the most extensive usage in China which accounts for about $70 \%$ in the two statistics. It is 14 percentage higher than the international average usage of $56.42 \%$.

TABLE IV. Changes of Choices of InVEntory Valuation Methods

\begin{tabular}{|l|c|c|c|c|c|}
\hline Mime & $\begin{array}{c}\text { Weight } \\
\text { ed } \\
\text { Average }\end{array}$ & FIFO & LIFO & $\begin{array}{c}\text { Specific } \\
\text { Identificati } \\
\text { on }\end{array}$ & Others \\
\hline 2005.12 .31 & $69.10 \%$ & $\begin{array}{l}6.47 \\
\%\end{array}$ & $\begin{array}{c}1.31 \\
\%\end{array}$ & $7.87 \%$ & $\begin{array}{l}15.24 \\
\%\end{array}$ \\
\hline 2009.12 .31 & $71.92 \%$ & $\begin{array}{l}7.49 \\
\%\end{array}$ & $/$ & $4.92 \%$ & 14.65 \\
\hline
\end{tabular}

Source: Wang Wenqing, 2011, Research on Inventory Earnings Management and Valuations of Internal Control

Through the analysis of Table 3.1 and Table 3.2, we can find out the choices of issued inventory valuation methods as follows: Firstly, the imbalance of choices of issued inventory valuation methods is common both at home and abroad with the weighted average method as the dominance. Secondly, compared with other countries, China has more serious imbalance of the choices of issued inventory valuation methods. Thirdly, after the cancellation of the LIFO method in China, although a part of the enterprises regard the FIFO method as scientific, changes of accounting system are more inclined to the weighted average method.

\section{B. Influence of Rising Prices on Issued Inventory valuation}

Inflation is one of the hot topics of recent years. Now, China, even the whole world, is in the inflation which can't be got rid of in a short period of time. China has been regulating the inflation all the time. In inflation, the increase in price is unavoidable. It is true of the prices of concerning inventory. The LIFO method will accelerate inflation, which makes it impractical in China.

Under the circumstance of prices soaring, the issued inventory valuation methods with the guidelines of the existing accounting standards can deal with the current situation. But as for the calculation of the inventory issuing in the enterprises, there are still some inevitable shortcomings which make it hard to reflect the current accounting information properly. In various inventory valuation methods, it is impossible to keep the differences between valuations of inventory balance and cost of sales of current period to a relatively small range. For instance, using the FIFO method will make enterprises' profits of current period on the high side. Therefore, there is still some room for improvement in the issued inventory valuation methods on the condition of inflation.

\section{SUGGESTIONS FOR THE MANAGEMENT OF INVENTORY VALUATION UNDER THE CURRENT CIRCUMSTANCE}

Under the current situation of issued inventory valuation methods, the problems in all aspects in China are more serious than that of the whole international community. China has to take measures according to the actual conditions with the purposes of promoting the changes of the current situation of issued inventory valuation and better serve our domestic market.

\section{A. Improving the Accounting Systems}

Under the circumstance of economic globalization, the accounting principles of different countries are becoming more and more convergent. Our national conditions differ from that of other developed countries as well as other developing countries. The particularities make the accounting standards in China in line with the mainline of IAS. But it does not need to be totally convergent with IAS by keeping its own accounting standards. However, in the future development, great attention still will be paid to the convergence between the accounting standards in China and the IAS.

In the aspect of issued inventory valuation, we have to constantly improve the accounting standards, letting them be more compatible with the current development conditions of China and, at the same time, be closer to the IAS. It will help China gain a more favorable position in the global development and promote the development of our 
international operation. For example, transnational corporations will confront fewer obstacles in handling the financial data, which will facilitate the operation of enterprises.

While integrating the Accounting Standards for Business Enterprises with IAS, China has to reasonably refine the choosing and operating of inventory valuation methods in order to enable the enterprises to operate in a more standardized way and improve the environment of issued inventory valuation. Combining Accounting Standards for Business Enterprises with our actual national conditions will contribute to solving the embarrassing situation that the inventory valuation faces in China.

\section{B. Strengthening the Training of Enterprises Managers}

The professional competence of the accountants and managers of enterprises will, to some degree, influence the quality of final accounting information. Strengthening the training of accountants and managers with constantly upgrading their accounting knowledge can do wonders for them to make concerning accounting decisions better.

Firstly, the corresponding accounting systems should be interpreted to the managers, including the accountants, letting them fully understand the quality requirements of accounting information and its significance and understand the requirements of the current inventory management so that enterprises can change the dominance of the weighted average method when they choose inventory valuation methods.

Secondly, accountants should receive good technical training, with which they can proficiently use various inventory valuation methods such as the FIFO method and so on. Meanwhile, good technical training can enable accountants to have sufficient ability and conditions for knowing and judging more suitable issued inventory valuation methods, creating a better environment for inventory calculation.

Thirdly, importance should be attached to the knowledge popularization of the methods which have been cancelled such as the LIFO method and to encourage the innovation in inventory valuation methods. For example, the LIFO method has been used until now in the America and imitated by many countries. Although it is on the way towards extinction, its appearance and recent development witness its reasonability that it once had. Knowing of the advantages and disadvantages of all kinds of inventory valuation methods and establishing right understanding can enhance the general recognition of inventory and promote the innovation in inventory valuation. A good example is that the latest valuation method proposed recently which make good advantage of the LIFO theory.

\section{Implementing Pilot Work of New Inventory Valuation Methods}

In recent years, new inventory valuation methods have been put forward constantly, many of which have integrated the strength of several methods such as the widely-used next-high, first-out method, last invoice price method and the latest inventory valuation method. [7]The appearance of these new methods makes the inventory valuation has more choices and lays the foundation for more reasonable inventory valuation methods which adhere to the current economic situation.

With the appearance of new inventory valuation methods, corresponding departments can analyze their reasonability and feasibility. In the case that a method has certain reasonability and feasibility, they can carry out trial investigation on a small scale. The reason is that if the usage and spreading of a new accounting method starts directly, it may influence and impact the existing accounting environment, subsequently hamstring the stability of the whole accounting environment. Once failure happens, the bad influence can't be removed in a short period of time. [8]Thus in a certain period of time, it is necessary to carry out the pilot work of new inventory valuation methods within some regions, make record carefully, and analyze and summarize the recording processes and the results so as to judge whether the method is suitable for the current situation, thus consequently finding out the more practical inventory valuation methods safely and scientifically.

\section{REFERENCES}

[1] Chang Xun, Chang Liang, 2012, International Accounting, Northeast University of Finance and Economics Press, PP 10-73.

[2] Guo Yanmeng, 2012, Research on Choices of Enterprise Inventory Valuation Methods and Taxing Planning, Friends of Accounting, the first half of the second issue, P86-88.

[3] Huang Lan, 2011, Comparison between China and Malaysia in Inventory Accounting Principles, Guangxi College of Finance and Economics Journals, the fourth issue of the $24^{\text {th }}$ volume, P11-14.

[4] Hou Junbang, 2011, Analysis of the Influence of the Choices of Accounting Systems on Enterprise Tax Burden--- with the Example of the Choices of Inventory Valuation Methods, Financial Communications, the first half of the $10^{\text {th }}$ issue, P95-96.

[5] Lao Chuanqi, 2011, Research on the Accounting Cultural Background of the Global Convergence of Accounting Principles, working paper.

[6] Ma Li, 2011, Exploration of the Issued Inventory Valuation Methods of Manufacturing Enterprise, Economic Forum, the first issue, P46.

[7] Qiao Yanjing, 2011, The Choices of Inventory Valuation Methods of Modern Enterprises, Research on Enterprises, the $16^{\text {th }}$ issue, P82-83

[8] Song Haixia, 2012, Exploration of enterprise Issued inventory Cost Valuation Methods with the Calculation of Actual Cost, Economic Research Guide, the $451^{\text {th }}$ issue, P82-83. 